\title{
EUROPE AT THE CROSSROADS: THE CHALLENGE FROM INNOVATION-BASED GROWTH
}

\author{
Professor Jan Fagerberg \\ Centre for Technology, Innovation and Culture, \\ University of Oslo
}

For presentation at the ERC/METU INTERNATIONAL

CONFERENCE IN ECONOMICS IV, September 13-16, 2000,

Ankara, Turkey

Address for correspondence:

Professor Jan Fagerberg

Centre for technology, innovation and culture

University of Oslo

Gaustadalléen 21

P.O. Box 1108 Blindern

0349 OSLO

Norway

E-mail: jan.fagerberg@tik.uio.no 



\section{ABSTRACT}

Europe's performance relative to the US and countries in Asia is a topic that greatly preoccupies policy-makers who are concerned that the EU is losing ground compared to other, more dynamic parts of the world. Although the recent crises in Asia gave a timely reminder that the grass often looks greener on the other side of the fence, this paper points to trends in EU performance that European policy-makers will find disconcerting. Productivity growth has slowed down relative to competitors. Export competitiveness has deteriorated in all areas except agriculture and raw materials. The losses have been most manifest in the technologically most sophisticated industries, particularly ICT. Europe has also failed to create employment on a scale at all comparable with the US or Japan, with obvious repercussions for unemployment. While until recently there was a tendency towards convergence in productivity and income between European regions, there are now signs of a reversal of this trend. Redressing this relatively disappointing performance will be neither easy nor quick, but if enduring answers to Europe's problems are to be found, it is essential that the scale and nature of these problems are carefully diagnosed and solutions found. This paper argues that the problems that Europe faces in key areas such as growth, equality and employment are all related to its failure to take sufficient advantage of technological advances, particularly the ICT revolution. Consequently, a coherent European strategy for upgrading technological capability and quality competitiveness is long overdue. This cannot be limited to providing support to selected industries (or companies) in order to make them more competitive in global markets. Rather, what Europe has to do is to take steps to embed new technologies in society. This should bring together macro-economic policy, regulation, science and technology policy, and employment initiatives. The complementarities between policy areas, in particular, should be stressed. 



\section{INTRODUCTION ${ }^{1}$}

Europe's performance relative to the US and countries in Asia is a topic that greatly preoccupies policy-makers who are concerned that the EU is losing ground compared to other, more dynamic parts of the world. Although the recent crises in Asia gave a timely reminder that the grass often looks greener on the other side of the fence, this paper points to trends in EU performance that European policy-makers will find disconcerting. Productivity growth has slowed down relative to competitors. Export competitiveness has deteriorated in all areas except agriculture and raw materials. The losses have been most manifest in the technologically most sophisticated industries, particularly ICT. Europe has also failed to create employment on a scale at all comparable with the US or Japan, with obvious repercussions for unemployment. While until recently there was a tendency towards convergence in productivity and income between European regions, there are now signs of a reversal of this trend. Redressing this relatively disappointing performance will be neither easy nor quick, but if enduring answers to Europe's problems are to be found, it is essential that the scale and nature of these problems are carefully diagnosed and solutions found.

\section{A LONG VIEW}

In terms of productivity (as measured by GDP per capita) Europe seems to be surpassed not only by the US, but also by Japan and - if the trends from the past decades prevail in the next century - by a number of other Asian economies as well. How did this happen? One or two centuries ago, the situation was entirely different. During most of the nineteenth century the UK was the leading capitalist country in the world, with a GDP per capita about 50 per cent above the average of other leading capitalist countries (Table 1). However, during the second half of the century, the US started to catch up with the UK and eventually - around 1910 - surpassed it. In retrospect it becomes clear that US growth was based on a new technological system, based on large-scale production and distribution systems well suited for the large, fastgrowing and relatively homogenous American market (Chandler, 1990; Nelson and Wright, 1992).

\footnotetext{
${ }^{1}$ This paper is based on a recently published book from the project, «The economic challenge for Europe: Adapting to innovation-based growth» (Edward Elgar, 1999). I wish to thank my co-authors, particularly Iain Begg, Paolo Guerrieri and Bart Verspagen, for their permission to use our joint work for this purpose.
} 
That Europe initially failed to take advantage of these innovations is perhaps not so difficult to explain. The European markets were smaller and less homogenous. Hence, it is not obvious that US methods, if applied to European conditions in this period, would have yielded superior results. This is what Abramovitz (1994) has dubbed a lack of 'technological congruence'. Two world wars and an intermediate period of protectionism and slow growth added to these problems (Abramovitz, 1994). Hence, the US lead increased even further and peaked around 1950, when GDP per capita in the US was about twice the European level. 
Table 1. GDP per capita in the industrialised world, 1820-1994 (1000 1990 US\$ per head)

\begin{tabular}{|c|c|c|c|c|c|c|c|c|c|c|}
\hline & 1820 & 1870 & 1910 & 1950 & 1970 & 1980 & 1990 & 1994 & $\begin{array}{r}\text { Growth } \\
1820-1950\end{array}$ & $\begin{array}{r}\text { Growth } \\
1950-94(90)\end{array}$ \\
\hline USA & 1.3 & 2.5 & 5.0 & 9.6 & 14.9 & 18.3 & 21.9 & 22.6 & 1.5 & 2.0 \\
\hline Japan & 0.7 & 0.7 & 1.3 & 1.9 & 9.4 & 13.1 & 18.5 & 19.5 & 0.8 & 5.3 \\
\hline Germany & 1.1 & 1.9 & 3.5 & 4.3 & 11.9 & 15.4 & 18.7 & 19.1 & 1.0 & 3.4 \\
\hline France & 1.2 & 1.9 & 2.9 & 5.2 & 11.6 & 15.0 & 17.8 & 18.0 & 1.1 & 2.8 \\
\hline Italy & 1.1 & 1.5 & 2.3 & 3.4 & 9.5 & 13.1 & 16.0 & 16.4 & 0.9 & 3.6 \\
\hline United Kingdom & 1.8 & 3.3 & 4.7 & 6.8 & 10.7 & 12.8 & 16.3 & 16.4 & 1.0 & 2.0 \\
\hline Canada & 0.9 & 1.6 & 3.9 & 7.0 & 11.8 & 16.3 & 19.6 & 18.4 & 1.6 & 2.2 \\
\hline Belgium & 1.3 & 2.6 & 4.0 & 5.3 & 10.4 & 14.0 & 16.8 & 17.2 & 1.1 & 2.7 \\
\hline Netherlands & 1.6 & 2.6 & 3.7 & 5.9 & 11.7 & 14.3 & 16.6 & 17.2 & 1.0 & 2.5 \\
\hline Korea & & & & 0.9 & 2.2 & 4.1 & 9.0 & & & 5.8 \\
\hline Taiwan & & & 1.0 & 0.9 & 2.7 & 5.6 & 10.3 & & & 6.0 \\
\hline Hong Kong & & & & 2.0 & 5.3 & 10.0 & 17.1 & & & 5.4 \\
\hline \multicolumn{11}{|l|}{ Europe (6) } \\
\hline Mean & 1.3 & 2.3 & 3.5 & 5.2 & 11.0 & 14.1 & 17.0 & 17.4 & 1.0 & 2.8 \\
\hline Coeff. Of Var. & 0.18 & 0.26 & 0.22 & 0.21 & 0.08 & 0.07 & 0.05 & 0.05 & & \\
\hline
\end{tabular}

All countries except Asian

NICs

Mean

$\begin{array}{llll}1.2 & 2.1 & 3.5 & 5.5\end{array}$

$\begin{array}{llll}11.3 & 14.7 & 18 & 18.3\end{array}$

1.2

Coeff. Of Var.

$\begin{array}{llll}0.25 & 0.35 & 0.32 & 0.38\end{array}$

All countries

Mean

$\begin{array}{rrrr}4.4 & 9.3 & 12.7 & 16.5 \\ 0.59 & 0.4 & 0.32 & 0.21\end{array}$

Coeff. Of Var.

Source: Fagerberg, Guerrieri and Verspagen (1999) based on data from Maddison (1995) and data kindly supplied by Angus Maddison .

Notes: 1. For Korea, Taiwan and Hong Kong, the final period is 50-90, not 50-94.

2. Europe (6) is the six European countries in the table. 
While the period between 1820 and 1950 was one of divergence in economic performance between leading capitalist countries, the following period has generally been one of convergence. The productivity gap between the US and Europe has been significantly reduced. This reduction, most of which occurred during the 1950s and 1960s, was related to the potential for rapid productivity advance in Europe through imitation (of superior US technology). European production and exports in industries such as cars, domestic electrical equipment, electronics etc. grew rapidly from the 1950s onwards. The gradual reduction of barriers to trade within Europe from the 1950s onwards has generally been regarded as an important contributing factor to this process, as has the general rise in living standards (Abramovitz, 1994; Maddison, 1991).

European countries were not alone, however, in exploiting the window of opportunity given by superior US technology. From the 1950s onwards Japan, later joined by other Asian economies, aggressively targeted the very same industries as those that had grown rapidly in Europe (Johnson, 1982; Wade, 1990). Initially this did not give much reason for concern among European policy-makers or industrialists. But during the 1970s and 1980s it became evident that Japanese suppliers outperformed their European and US competitors in many cases, and that this could not be explained solely by low wages. In became clear that the Japanese, as the Americans before them, had made important innovations in the organisation of production, innovations that have led to both increased quality and higher productivity (Von Tunzelmann, 1995), and which US and European competitors - despite serious efforts - have not yet managed to imitate to the extent that they would have wished.

While Europe, Japan and other countries started to catch up in many typical 'American way of life' products, US industry leaped forward in another area; sciencebased industry, in part due to massive public investments in R\&D during the Second World War and the «cold war» that followed. Gradually, however, European countries and Japan started to devote more resources to science and R\&D (Table 2). By the mid1970s many of these countries used a larger share of their available resources on civil R\&D than did the US. Hence the US lead started to be challenged in this area as well. Following the Japanese example, some of the Asian NICs started to invest massively in $R \& D$ from the 1970 s onwards. 
Table 2. Estimates of non-defence $R \& D$ as a percentage of GDP (selected years)

$1963 \quad 1973 \quad 1981 \quad 1993$

$\begin{array}{lllll}\text { USA } & 1.5 & 1.7 & 1.9 & 2.1 \\ \text { Japan } & 1.4 & 1.9 & 2.4 & 2.8 \\ \text { Germany } & 1.3 & 2.0 & 2.4 & 2.3 \\ \text { France } & 1.2 & 1.5 & 1.7 & 2.1 \\ \text { Italy } & 0.7 & 0.9 & 1.0 & 1.3 \\ \text { United Kingdom } & 1.5 & 1.6 & 1.9 & 1.8 \\ \text { Canada } & 1.0 & 1.1 & 1.2 & 1.6 \\ \text { Belgium } & 1.0 & 1.4 & 1.4 & 1.6 \\ \text { Netherlands } & 2.0 & 2.0 & 1.9 & 2.0 \\ \text { Sweden } & 0.9 & 1.4 & 2.0 & 3.0 \\ \text { Switzerland } & 2.5 & 2.3 & 2.3 & 2.6 \\ \text { Korea } & 0.3 & 0.3 & 0.8 & 2.3 \\ \text { Taiwan } & 0.4 & & 0.7 & 1.8\end{array}$

Europe (6)

$\begin{array}{lllll}\text { Mean } & 1.3 & 1.6 & 1.7 & 1.9 \\ \text { Coeff. Of var. } & 0.3 & 0.2 & 0.2 & 0.2\end{array}$

All countries except Asian NICs

$\begin{array}{lllll}\text { Mean } & 1.4 & 1.6 & 1.8 & 2.1 \\ \text { Coeff. Of var. } & 0.4 & 0.2 & 0.2 & 0.2\end{array}$

All countries

$\begin{array}{lllll}\text { Mean } & 1.2 & 1.4 & 1.7 & 2.1 \\ \text { Coeff. Of var. } & 0.5 & 0.4 & 0.3 & 0.2\end{array}$

Source: Fagerberg, Guerrieri and Verspagen (1999) based on data from OECD Science and Technology Indicators Database and UNESCO/national sources (Korea, Taiwan).

Note: Estimates of civil R\&D are available for most OECD countries for selected years. These estimates show that for all but a few countries (notably the USA, the UK, France and Sweden) differences between civil and total $R \& D$ are small. Hence, for some countries and years, total $R \& D$ is used instead. Since data are not always available annually, the data reported here will in some cases be based on information from a preceding and/or following year. For definition of Europe (6), see Table 1. 
During the 1980s European catch-up vis-à-vis the US came to a halt, while Japan continued to increase productivity at a faster rate than both the US and Europe. As a consequence Japan now enjoys a higher level of GDP per capita than Europe. The Asian NICs (Hong Kong, Korea and Taiwan) have - at least until recently - continued to experience very rapid productivity growth, i.e., to catch-up relative to the US and other countries.

\section{EUROPE IN THE GLOBAL MARKET}

Technological catch-up (or lack of such) and structural changes are intimately related with trade performance. In fact, one of the striking findings from studies of successful catch-up is that it is associated with both a general improvement in trade performance and a radical change in the composition of trade. For instance, the catch-up of Europe and Japan in scale- and capital-intensive technologies from the 1950s onwards was associated with rapidly increasing export market shares for products embodying these technologies. However, since then the locus of growth within manufacturing has changed to science-based industries.

How has Europe adapted to these changes in the global market? To answer this question we will, following work by Pavitt $(1984,1988)$ and Guerrieri (1992), make use of a taxonomy in which industries are allocated to sectors depending on the nature and sources of technological knowledge. In principle such taxonomy could have been applied to both goods and services, but because of data limitations we confine the analysis here to the former. The taxonomy identifies five type of industries: agricultural products and raw materials, traditional manufactures, scale-intensive, specialised suppliers (of various types of machinery, instruments etc.) and, finally, science-based industries (such as professional electronics, pharmaceuticals and aerospace). The two former depend largely on technology developed in other sectors, while the two latter are typical «technology producing» sectors serving the entire economy. Scale intensive industry is in an intermediate position in this regard, it receives a lot of its technology from others, but it also has significant in-house technological accumulation (learning). Among these industries, science based industry has displayed the highest growth recently. Between 1970 and 1995 the share of science based products in total world trade more than doubled, largely at the expense of agricultures and raw materials (Fagerberg, Guerrieri and Verspagen 1999). 
Table 3 reports market shares (ratio of national exports to world exports) for four major players in the global economy, Europe (15), the United States, Japan and the Asian NICs between 1970 and 1995. The market shares for Europe reported in the table include intra-European trade, and this explains why Europe's market shares are so high compared to the United States and Japan. However, similar calculations were made excluding intra-European trade, and the trends (changes through time) - which is what commands interest here - were basically the same. Between 1970 and1995 Japan and the Asian NICs gained market shares at the expense of the US and Europe. In particular, the Asian NICs showed a spectacular performance; between 1970 and 1995 its overall market share increased more than five times, from 2.1 to 10.8 per cent of the global market. It is also noteworthy that the rapid growth of Japan and the Asian NICs was accompanied by very rapid structural changes that totally changed the specialisation pattern of these countries. In the case of Japan, in spite of overall market share growth, the market shares for traditional and scale- intensive industries actually contracted, while those of specialised suppliers and science-based industry increased rapidly, so that by the end of the period Japan had its major strength in the latter (followed by scale-intensive industry). For the Asian NICs a similar development took place, with a much stronger growth in science-based industry and specialised suppliers than in the traditional area of strength (traditional industries).

In contrast to the Asian experience, both Europe and the US lost overall market shares. Moreover, these losses were generally more manifest in high- technology sectors, particularly science-based industries, than elsewhere. As a consequence, in the 1990s Europe was no longer specialised (i.e., having an above average market share) in science-based industry. The only area in which Europe gained market shares was agricultural products and raw materials. Hence, European competitiveness, whether measured through its growth or trade performance, is deteriorating. Moreover, slow growth and declining market shares, particularly in the most advanced and fastgrowing industries, go hand in hand with increasing unemployment problems (Table $4)$. 
Table 3 Market shares 1970-1995 (ratio of national exports to world exports*, per cent)

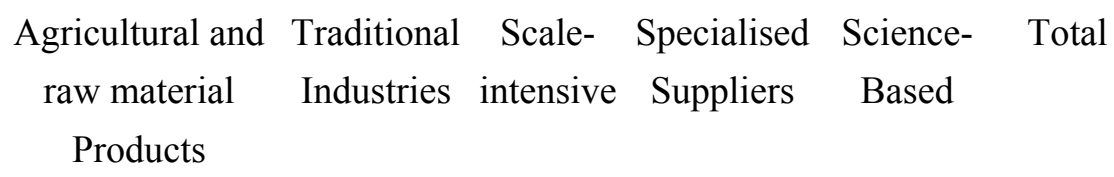

\begin{tabular}{|c|c|c|c|c|c|c|c|}
\hline Europe & 1970 & 24.1 & 57.0 & 55.7 & 61.2 & 48.6 & 44.6 \\
\hline \multirow[t]{4}{*}{ (15) } & 1988 & 30.3 & 47.6 & 51.2 & 56.0 & 41.3 & 44.0 \\
\hline & 1995 & 31.6 & 40.1 & 47.3 & 47.6 & 33.8 & 39.6 \\
\hline & Change & & & & & & \\
\hline & 1970-95 & 7.5 & -16.9 & -8.4 & -13.6 & -14.8 & -5.0 \\
\hline \multirow[t]{5}{*}{ US } & 1970 & 13.1 & 7.4 & 14.5 & 22.3 & 29.5 & 14.8 \\
\hline & 1988 & 13.4 & 5.2 & 9.4 & 12.2 & 19.8 & 11.6 \\
\hline & 1995 & 11.0 & 6.7 & 10.3 & 13.7 & 17.9 & 11.8 \\
\hline & Change & & & & & & \\
\hline & 1970-95 & -2.1 & -0.7 & -4.2 & -8.6 & -11.6 & -3.0 \\
\hline \multirow[t]{5}{*}{ Japan } & 1970 & 1.2 & 9.3 & 13.8 & 6.4 & 7.7 & 6.7 \\
\hline & 1988 & 1.1 & 4.1 & 17.1 & 15.6 & 16.7 & 10.1 \\
\hline & 1995 & 1.4 & 3.2 & 12.8 & 15.7 & 14.3 & 9.0 \\
\hline & Change & & & & & & \\
\hline & 1970-95 & 0.2 & -6.1 & -1.0 & 9.3 & 6.6 & 2.3 \\
\hline \multirow[t]{5}{*}{ Asian NICs } & 1970 & 2.0 & 6.1 & 1.0 & 0.8 & 1.0 & 2.1 \\
\hline & 1988 & 2.6 & 14.5 & 5.6 & 4.0 & 9.1 & 6.7 \\
\hline & 1995 & 3.4 & 16.2 & 8.7 & 8.8 & 17.8 & 10.8 \\
\hline & Change & & & & & & \\
\hline & $1970-95$ & 1.4 & 10.1 & 7.7 & 8.0 & 16.8 & 8.7 \\
\hline
\end{tabular}

Europe (15): Austria, Belgium, Denmark, Finland, France, Germany, Greece, Ireland,

Italy, Luxembourg, Netherlands, Portugal, Spain, Sweden, United Kingdom.

Asian NICs: Hong Kong, Korea, Singapore, Taiwan.

* Goods exports (trade in services not included). For the definition of sectors see Fagerberg, Guerrieri and Verspagen 1999, appendix to chapter 1.

Source: Fagerberg, Guerrieri and Verspagen (1999) based on UN and OECD data from the SIE World Trade data base. 
Table 4 Unemployment as a percentage of the total labour force

$\begin{array}{lcccc} & 1960-1973 & 1974-1979 & 1980-1989 & 1990-1995 \\ \text { Europe (15) } & 2.3 & 4.6 & 9.2 & 9.8 \\ \text { USA } & 4.8 & 6.7 & 7.2 & 6.4 \\ \text { Japan } & 1.3 & 1.9 & 2.5 & 2.5 \\ \text { Korea } & \mathrm{Na} & 3.8 & 3.8 & 2.4\end{array}$

Source and definitions: Fagerberg, Guerrieri and Verspagen (1999) based on data from OECD Historical Statistics 1960-1995.

\section{EUROPEAN ECONOMIC INTEGRATION}

It is pertinent to ask what European integration has to do with all this. 40-50 years ago, when the first steps towards the present-day European Union were taken, priority was initially given to the creation of a common market for natural resource-based industries such as the coal and steel industries and agriculture. Because of the political sensitivity of these industries, the steps towards a common market were often combined with subsidies for high-cost, uncompetitive producers, and in many cases these subsidies became of a permanent (or semi-permanent) nature. In agriculture, a strong and costly incentive scheme was created, the Common Agricultural Policy (CAP), that encouraged agricultural production. As a result, Europe has become selfsufficient for most agricultural products and a problem of surpluses has occurred, that is being resolved through among other things subsidised exports. Hence, it comes as no surprise that Europe has increased its market shares internationally for agriculture and raw materials.

The other main element in the European economic integration process has been a continuous drive towards economies of scale through enlargement and homogenisation of markets. After the Second World War various schemes were developed in order to facilitate trade across national borders in Europe. From the late 1950s onwards a process of trade liberalisation took place within two European trading blocks, EEC and EFTA. By the early 1970s internal trade in manufactures was virtually free of tariffs and other restrictions within these two blocks. These developments clearly strengthened the catch-up of Europe in many scale-intensive industries previously dominated by US industry such as cars, domestic electrical equipment and consumer electronics.

The drive towards economies of scale through enlargement of markets continued in the 1970s with the integration of the member countries of the two former trading 
blocks, EEC and EFTA. By the mid-1980s Western Europe had become a free-trading area for manufactures. However, this failed to produce positive growth effects of the type that had been associated with previous integration efforts. Partly as a result of this the EU launched its plan for a revitalisation of the internal European market ('Europe 1992'). This plan was based on the idea that there were large unexploited economies of scale in European industry, the exploitation of which had been prevented by the existence of so-called 'non-tariff barriers' to trade, commonly assumed to be related to discriminatory actions by governments in one way or another. Hence, the heart of the plan has been to abolish these barriers. The fact that Europe's trade performance has been slightly better in scale-intensive industry than in manufacturing as a whole, indicates that although it is difficult to detect an effect on overall growth, the strong emphasis on scale in European integration efforts may have had an impact on its pattern of specialisation.

To sum up, European integration has favoured natural resource-based and scaleintensive industries, and this is consistent with the observed change in its pattern of specialisation. However, given that modern growth is increasingly knowledge-based (Fagerberg, 1994), it seems relevant to ask to what extent this move away from the technologically most advanced and fast-growing parts of manufacturing poses a problem for Europe's future growth and welfare.

\section{CHALLENGES FROM INNOVATION-BASED GROWTH}

Traditional economic theory tells us that specialisation is beneficial in itself because it leads to more efficient use of available resources. However, unless this has a positive effect on technological progress (so-called 'dynamic economies of scale'), it will not lead to higher growth in the long run. Our research (Begg et al., 1999) shows that what matters for growth and competitiveness is not so much increasing the degree of specialisation in general, as the ability to exploit areas of high technological opportunity, which in recent years have been dominated by ICTs. 
Table 5. Some indicators on the use of ICT, 1996

\begin{tabular}{|c|c|c|c|c|c|c|}
\hline & Cellular & Internet & Internet & Personal & ISDN & ank \\
\hline & phone (1) & hosts (2) & users (2) & computers & subscribers & (3) \\
\hline & & & & (1) & (2) & \\
\hline Norway & 28.7 & 34.2 & 113.8 & 28.5 & 10.0 & 1 \\
\hline Finland & 29.2 & 61.3 & 167.8 & 19.5 & 7 & 2 \\
\hline Denmark & 25.0 & 20.3 & 57.0 & 30.4 & 5.7 & 3 \\
\hline US & 16.5 & 37.9 & 78.8 & 36.2 & 3.3 & 4 \\
\hline Switzerland & 9.3 & 18.7 & 52.1 & 40.9 & 17.7 & 5 \\
\hline Sweden & 28.2 & 26.9 & 90.5 & 21.5 & 2.2 & 6 \\
\hline UK & 12.2 & 12.4 & 43.0 & 19.3 & 4.5 & 7 \\
\hline Canada & 11.4 & 20.1 & 66.7 & 24.4 & 0.1 & 7 \\
\hline Germany & 7.1 & 8.4 & 30.5 & 23.3 & 23.7 & 9 \\
\hline Netherlands & 5.2 & 17.4 & 58.0 & 23.2 & 6.4 & 10 \\
\hline Japan & 21.4 & 5.8 & 55.7 & 12.8 & 4.2 & 11 \\
\hline Austria & 7.4 & 11.0 & 37.2 & 14.9 & 5.2 & 12 \\
\hline Belgium & 4.7 & 6.4 & 29.5 & 16.7 & 5.4 & 13 \\
\hline Ireland & 8.2 & 7.6 & 22.7 & 17.0 & 0.0 & 14 \\
\hline France & 4.2 & 4.1 & 8.6 & 15.1 & 7.3 & 15 \\
\hline Italy & 11.2 & 2.6 & 10.2 & 9.2 & 1.8 & 16 \\
\hline Portugal & 6.7 & 2.4 & 23.2 & 6.7 & 2.0 & 17 \\
\hline Spain & 3.3 & 2.9 & 13.4 & 9.4 & 0.9 & 18 \\
\hline Greece & 5.3 & 1.6 & 14.3 & 3.5 & 0.0 & 19 \\
\hline Europe (4) & 8.8 & 8.7 & 29.7 & 16.9 & 8.4 & \\
\hline $\begin{array}{l}\text { (1) subscribe } \\
\text { columns, }\end{array}$ & per 100 inl & jitants, (2) & 1000 in & abitants, (3) & mean rank & \\
\hline (4) weighted & n of count & above. & & & & \\
\hline Source: Dal & et al. (1 & 9a) based & data $f$ & om ITU W & orld Teleco & ions \\
\hline
\end{tabular}

However, as pointed out above, during the last decades Europe has lost ground in the technologically most progressive industries, and ICT is no exception to this trend. In fact, the research shows that, with the exception of telecommunication equipment, Europe has fallen behind the United States and Japan as suppliers to non-EU markets, and is increasingly vulnerable in software and services as well (Dalum et al., 1999a). The diffusion of ICT products and services in Europe is also slow (Table 5), particularly when compared to the United States, and very uneven across Europe. While some smaller countries, especially the Nordic ones, have diffusion rates similar 
(or superior) to the US level, most countries in Europe (particularly in the South) are laggards when it comes to use of ICTs.

This raises the issue of what policy-makers can and should do to reverse this uncomfortable trend. Arguably, transforming the education and training systems in order to equip individuals with the skills needed for an environment in which the major new technology is pervasive should be high on the policy agenda. The continuing skill shortages in software testify to the failure of Europe to meet this challenge, and it is evident that this deficiency has slowed the diffusion of ICTs beyond the immediate sectors that developed and applied them. However, acquiring skills is only a necessary first step. Skills also have to be put to uses that maximise diffusion and learning. Therefore a combination of enhancement of skills and diffusion-oriented policies centred on social needs is required. Mobile communications in the Nordic area is a good example of how public regulation and support managed to bring together new technology, skills and existing social needs in a way that both led to rapid diffusion of the new technology and - through learning the development of globally competitive firms and industries (Dalum, Fagerberg and Jørgensen, 1988). The possibility that similar policies also may work for other types of ICT applications should encourage policy-makers to experiment further with diffusion-oriented policies centred on users and social needs.

In a way the challenge for policy-makers is no less than devising solutions which restore the dynamism and creativity that characterised the European economy in earlier periods. Part of the answer has to do with getting a proper understanding of the 'system of innovation', the mix of characteristics, infrastructure and policies that determines how well an economy is able to exploit opportunities afforded by new technologies. In fact, differences in invention and innovation would not matter much if knowledge spread readily from region to region. However, the research reveals that the greater the geographical distance between regions, the lower the degree of knowledge flows between them (Maurseth and Verspagen, 1999). Moreover, knowledge flows are greater within countries than between them, suggesting that the national element in innovation systems remains strong. The research also shows that knowledge flows are most intense between regions with similar or complementary specialisation patterns, as well as between technologically linked sectors. These results suggest powerful influences leading to the formation of geographically concentrated clusters of technologically related activities at work in Europe's economy.

Economic and social cohesion - usually defined in terms of equity considerations such as regional disparities or social inclusion - is a fundamental aim of the EU 
articulated in Article 2 of the Treaty. However, research shows that regional disparities in economic performance remain substantial, and have increased in many member countries in the last decade (Fagerberg and Verspagen, 1996; Cappelen, Fagerberg and Verspagen, 1999), see Table 6. This gap is especially marked as regards innovative activity. Hence, what seems to be a fairly robust finding is that there exists a subgroup of high R\&D, high income regions in Europe with its own internal dynamics. What distinguishes these high $R \& D$ regions from the rest is mainly that $R \& D$ matter a lot in the former, while it is of little importance (or contributes negatively) in the latter. Thus, there is a risk that a faster rate of innovation, which is vital for European growth and competitiveness in general, might further aggravate regional disparities.

Table 6. Dispersion of GDP per capita in EU regions and countries 1960-1995

\begin{tabular}{lrrrr}
\hline & 1960 & 1970 & 1980 & 1995 \\
\hline Regional standard deviation EU9 & 0.34 & 0.27 & 0.20 & 0.21 \\
National standard deviation EU9 & 0.26 & 0.23 & 0.18 & 0.17
\end{tabular}

Share of total regional dispersion in EU9 due to:

\begin{tabular}{lllll} 
Between country dispersion in per cent & 64 & 79 & 52 & 41 \\
Within country dispersion in per cent & 36 & 21 & 48 & 59 \\
\hline
\end{tabular}

Note.

Regional standard deviation measures the dispersion across European regions independent of which country the regions belong to. National standard deviation measures the dispersion across European countries (disregarding the dispersion between regions within countries). EU 9 includes Denmark, BeNe-Lux, France, Germany, Ireland, Italy and UK. All figures based on PPS (purchasing power standard). The regional disaggregation is more detailed from 1980 onwards, and this biases the figures before 1980 for EU9 downwards.

Source: Cappelen, Fagerberg and Verspagen (1999) based on data from EUROSTAT (REGIO Data Base)

Although data are scarce on many factors of potential relevance for regional growth, the evidence clearly indicates that most low-income regions have failed to exploit the potential for technology diffusion. This points to a need for policies aimed at enhancing the capacity of such regions to absorb new technologies, especially ICTs. Similar issues arise in relation to the eastern enlargement anticipated in the next few years (Grabbe, Hughes and Landesmann, 1999) The research also drew attention to the potential for the local science base, in the form of university research, to contribute to 
local learning processes and, hence, regional development (Dalum et al., 1999b). Furthermore, the low rate of diffusion is often associated with a structure of activity dominated by agriculture or 'older' industries, and a corresponding lack of high-tech activities, often combined with relatively high unemployment. One strategy for change would be to reorient policies in this area towards accelerating structural change. But is its important to design policies in a way that does not lead to a further increase in longterm unemployment, as this is itself a factor hampering diffusion and growth (Fagerberg, Verspagen and Caniëls 1997).

Perhaps the most important problem facing EU policy-makers is how to combat the persistent high rate of unemployment in Europe (Table 4), which threatens social cohesion. It is important to stress that innovation is, in itself, no 'quick fix' for unemployment. Product innovation may increase employment through increased demand for products embodying the new technologies. But process innovation aimed primarily at rationalisation of existing production processes may also reduce employment in a specific industry and/or location, if not compensated by indirect income and demand effects. In contrast to the situation in the other parts of the 'triad', the latter (employment-reducing) type of outcome is in fact the most common in Europe (Pianta and Vivarelli, 1999). This is especially evident in industry (Table 7). What this implies is that Europe's industrial structure is orientated towards sectors most open to labour saving, mostly mature industries characterised by a high degree of process innovations.

Table 7. The relationship between growth of employment and growth of GDP/value added (elasticity), 1975-1996

\begin{tabular}{llll}
\hline Country & Whole Economy & Industry & Services \\
\hline United States & 0.6 & 0.4 & 0.6 \\
Japan & 0.3 & 0.2 & 0.4 \\
Europe (15) & 0.1 & -1.2 & 0.4 \\
\hline
\end{tabular}

Source: Pianta and Vivarelli (1999) based on data from the OECD, UN and Datastream.

Thus the challenge for policy-makers is not only to increase innovation-diffusion, but also to do so in a way that is more 'employment friendly'. This requires a shift from the traditional emphasis on process innovations and reduction of labour costs to a stronger focus on product innovations and increases in quality. It should be evident 
that Europe can never hope to compete with newly industrialised countries in Asia and elsewhere on the basis of labour costs alone, and that the long-run outlook for Europe is also influenced by the quality of what it produces. The research shows that there is great scope for raising quality as the core competitive advantage of the EU through a strategy based on product innovation, upgrading of skills and increased R\&D efforts (Jansen and Landesmann, 1999).

\section{CONCLUSIONS}

To some extent Europe's current problems is the price to be paid for past successes. European integration, most recently through the single market programme, has made product and factor markets more open and paved the way for the realisation of economies of scale and a more efficient allocation of resources. From a long-run perspective, these policies have been extremely successful. Without them, it is doubtful whether Europe would have managed to catch up with the US to the extent that it did. However, the rewards to catch-up in capital- and scale-intensive sectors producing for the mass markets have been cashed in long ago, and now the rules of the game have changed. In the last decades, science-based industries, especially those drawing heavily on ICTs, have become the main driver of technological change and economic growth. Although the ICT revolution has been under way for a long time, its major effects are just beginning to be felt and it is clear that Europe's performance in ICT, however measured, is far from satisfactory. It is our contention that a mere continuation of past policies will not suffice to reverse this discomforting trend. If appropriate steps are not taken now, it is our assessment that the current trends toward slow growth, increasing inequality and unemployment will continue, threatening social cohesion, the social model and the democratic values that Europeans hold dear.

The story is easily told. Slow growth is mainly the result of failure to exploit the technological opportunities inherent in new and fast-growing technologies. This is not mainly a question of failing to be competitive in, say, the production of computers or other products embodying ICT, but embedding the new technology in society at large. Regional disparities have been exacerbated by the very uneven diffusion of new technology, which has, hitherto, disproportionately favoured high-income, high-R\&D regions specialised in high-tech manufacturing and - above all - services. By contrast, traditional agricultural regions or regions in the rustbelt have benefited very little if at all. Rather what has happened is that the relative prices of their products and factor 
services have declined. High unemployment is the flip side of this coin. Europe's continuing specialisation in increasingly mature industries characterised by laboursaving innovation has meant that relatively few new jobs have been created. Low labour mobility has made matters worse by inhibiting effective redeployment of resources and has, arguably, been an impediment to technological advance (Fagerberg, Verspagen and Caniëls, 1997)

Although the diagnosis is clear, agreeing on remedies is much less easy. What makes the problem so challenging is the need for actors and trends at very different levels to pull together. On the one hand, as the research shows, the creation of technological advantage is in most cases a very local affair. At the other extreme, radical technological changes, particularly the ICT revolution, affect nearly all aspects of life, so that a holistic approach to change aimed at exploiting the opportunities afforded by these new technologies is needed. Because of path dependency in local technological, institutional and economic systems, and the complex conditions for getting the most out of ICT, this is very difficult to realise in practice. Thus, there is a large co-ordination problem here, and this emphasises the need for a strategic view on European growth. What is needed is in our view a much more prominent role for the $\mathrm{EU}$, not only in policy co-ordination, but in discussing policy change, experimenting with policy alternatives, evaluating the results and providing benchmarking for government at various levels. Arguably, a much greater emphasis needs to be placed on stimulating more rapid, pervasive and effective innovation in technologies, organisations and institutions.

The core message from our research is that the problems that Europe faces in key areas such as growth, equality and employment are all related to its failure to take sufficient advantage of technological advances, particularly the ICT revolution. Consequently, a coherent European strategy for upgrading technological capability and quality competitiveness is long overdue. This cannot be limited to providing support to selected industries (or companies) in order to make them more competitive in global markets. Rather, what Europe has to do is to take steps to embed new technologies in society. This should bring together macro-economic policy, regulation, science and technology policy, and employment initiatives. The complementarities between policy areas, in particular, should be stressed. Equally, it is vital at the outset to recognise that change will not happen overnight and that boosting the long-run ability of the economy to create and use new technologies will require concerted action. 


\section{REFERENCES}

Abramovitz, M. (1994), 'The Origins of the Postwar Catch-Up and Convergence Boom', in Fagerberg, J. et al. (1994), pp. 21-52.

Begg, I., B. Dalum, P. Guerrieri and M. Pianta (1999) «The Impact of Specialization in Europe» in Fagerberg, J., P. Guerrieri and B. Verspagen (eds.) (1999)

Cappelen, A., J. Fagerberg and B. Verspagen (1999) «Lack of Regional Convergence» in Fagerberg, J., P. Guerrieri and B. Verspagen (eds.) (1999)

Chandler, Alfred D., Jr. (1990), Scale and Scope. The Dynamics of Industrial Capitalism, Cambridge (MA): The Belknap Press.

Dalum, B., J. Fagerberg and U. Jørgensen (1988), 'Small Countries in the World Market for Electronics: the Case of the Nordic Countries', in B.-A. Lundvall and C. Freeman, (eds), Small Countries Facing the Technological Revolution, London: Pinter Publishers.

Dalum, B., C. Freeman, R. Simonetti, N.von Tunzelmann and B. Verspagen (1999) «Europe and the Information and Communication Technologies Revolution» in Fagerberg, J., P. Guerrieri and B. Verspagen (eds.) (1999) (Dalum et al. 1999a)

Dalum, B., M. Holmen, S. Jacobsson, M. Præst, A. Rickne and G. Villumsen (1999) «Changing the Regional System of Innovation» in Fagerberg, J., P. Guerrieri and B. Verspagen (eds.) (1999) (Dalum et al. 1999b)

Fagerberg, J. (1994) «Technology and International Differences in Growth Rates», Journal of Economic Literature 32, 147-175

Fagerberg, J., B. Verspagen and N. von Tunzelman (eds.) (1994), The Dynamics of Technology, Trade and Growth, Aldershot: Edward Elgar.

Fagerberg, J. and B. Verspagen (1996), 'Heading for Divergence? Regional Growth in Europe Reconsidered', Journal of Common Market Studies, 34, 431-48.

Fagerberg, J., B. Verspagen and M. Caniëls (1997) «Technology, Growth and Unemployment across European Regions», Regional Studies, 31, 457-466

Fagerberg, J., P. Guerrieri and B. Verspagen (eds.) (1999) The Economic Challenge for Europe: Adapting to Innovation-based Growth, Aldershot: Edward Elgar (forthcoming)

Fagerberg, J., P. Guerrieri and B. Verspagen (1999) «Europe-a Long View» in Fagerberg, J., P. Guerrieri and B. Verspagen (eds.) (1999) 
Grabbe, H., K. Hughes and M. Landesmann (1999) «The Implications of EU Enlargement for EU Integration, Convergence and Competitiveness» in Fagerberg, J., P. Guerrieri and B. Verspagen (eds.) (1999)

Guerrieri, P. (1992), 'Technological and Trade Competition: the Changing Position of US, Japan and Germany', in M.C. Harris and G.E. Moore (eds.), Linking Trade and Technology Policies, Washington, DC: National Academy Press.

Jansen M. and M. Landesmann (1999) «European Competitiveness: Quality rather than Price» in Fagerberg, J., P. Guerrieri and B. Verspagen (eds.) (1999)

Johnson, C. (1982), MITI and the Japanese Miracle: The Growth of Industrial Policy, 1925-1975, Stanford: Stanford University Press.

Maddison, A. (1991), Dynamic Forces in Capitalist Development, New York: Oxford University Press.

Maddison, A. (1995). Monitoring the World Economy, 1820-1992, Washington, DC: Organization for Economic Cooperation and Development

Maurseth, P. and B. Verspagen (1999) «Europe: One or Several Systems of Innovation?» in Fagerberg, J., P. Guerrieri and B. Verspagen (eds.) (1999)

Nelson, R. R. and G. Wright (1992), 'The rise and fall of American technological leadership: The postwar era in historical perspective', Journal of Economic Literature, 30, 1931-64.

Pavitt, K. (1984), 'Patterns of Technical Change: Towards a Taxonomy and a Theory', Research Policy, 13, 343-74.

Pavitt, K. (1988), 'International Patterns of Technological Accumulation', in N. Hood and J.E. Vahlne (eds), Strategies in Global Competition, London: Croom Helm.

Pianta, M. and M. Vivarelli (1999) «Employment Dynamics and Structural Change in Europe» in Fagerberg, J., P. Guerrieri and B. Verspagen (eds.) (1999)

von Tunzelmann, G. N. (1995), Technology and Industrial Progress. The Foundations of Economic Growth, Aldershot: Edward Elgar.

Wade, R. (1990), Governing the Market. Economic Theory and the Role of Government in East Asian Industrialization, Princeton: Princeton University Press. 